\title{
HUBUNGAN ANTARA KEPERCAYAAN DIRI DENGAN KECEMASAN BERBICARA DI DEPAN UMUM PADA MAHASISWA PROGDI PENDIDIKAN SEJARAH UKSW SALATIGA
}

\author{
Claudia Verra Lisanias, J.T. Lobby Loekmono, Yustinus Windrawanto \\ Email: clisanias7@gmail.com,lobby.loekmono@staff.uksw.edu, \\ yustinuswindrawanto@uksw.edu \\ BK FKIP Universitas Kristen Satya Wacana Salatiga
}

\begin{abstract}
Abstrak
Penelitian ini dilaksanakan di progdi Pendidikan Sejarah UKSW Salatiga, dengan populasi seluruh mahasiswa progdi pendidikan sejarah yang berjumlah 80 orang mahasiswa dan merupakan sampel total. Penelitian ini bertujuan untuk mengetahui signifikansi hubungan antara kepercayaan diri dengan kecemasan berbicara di depan umum pada mahasiswa progdi pendidikan sejarah UKSW Salatiga. Alat ukur yang digunakan dalam penelitian ini adalah Self Confidence Scale yang disusun Lauster (2002) dan Personal Report of Public Speaking Anxiety yang disusun oleh Mc Croskey, J.C (2013). Teknik analisis yang digunakan dalam penelitian ini adalah Kendall"s tau yang diolah dengan bantuan program SPSS Version 21.0 for Windows. Hasil analisis data diperoleh bahwa ada hubungan negatif yang signifikan antara kepercayaan diri dengan kecemasan berbicara di depan umum yang ditunjukkan dengan hasil koefisien korelasi rxy $=-0,177$ dengan nilai sig (1-tailed) sebesar $0,006<0,05$. Artinya semakin rendah skor kepercayaan diri maka semakin tinggi skor kecemasan berbicara di depan umum, dan jika semakin tinggi skor kepercayaan diri maka semakin rendah kecemasan berbicara di depan umum.

Kata Kunci : Kepercayaan Diri, Kecemasan Berbicara di Depan Umum
\end{abstract}

\section{PENDAHULUAN}

Komunikasi merupakan hal yang sangat penting dalam kehidupan, meskipun demikian sebagian orang mengalami kesulitan untuk mengungkapkan apa yang hendak diinformasikan. Hasil studi pendahuluan yang dilakukan oleh Sari (2015) dengan responden 15 mahasiswa, 3 orang mengalami kecemasan (trait) berbicara di depan umum karena takut menguasai bahan yang akan disampaikan dan 12 orang mengalami kecemasan berbicara di depan umum dengan persentase $80 \%$ karena kurang percaya diri (Sari, 2015).
Percaya diri merupakan hal penting yang di butuhkan oleh calon guru dalam melakukan komunikasi dengan siswa, orang tua, kepala sekolah serta masyarakat. Sehingga guru dapat mengajar dengan baik tanpa mengalami kecemasan saat berbicara di depan umum. Kemampuan untuk berbicara di depan umum juga diperlukan oleh calon guru sehingga guru dapat memiliki rasa percaya diri dalam berbicara di depan umum.

Kepercayaan diri merupakan sikap atas kemampuan diri sendiri dalam tindakan-tindakannya, dapat merasa bebas untuk melakukan hal-hal yang 
disukainya dan bertanggung jawab atas perbuatannya, hangat dan sopan dalam berinteraksi dengan orang lain, dapat menerima dan menghargai orang lain, serta dapat mengenal kelebihan dan kekurangannya (Lauster, 2002).

Kepercayaan diri berpengaruh pada manusia, kepercayaan diri cenderung berubah, hal ini tergantung pada pengalaman dalam hubungan interpersonal, namun demikian pengalaman tidak hanya memberikan umpan balik yang positif saja, bila umpan balik yang diterima positif maka kepercayaan diri akan membaik, sebaliknya jika umpan balik yang diterima negatif maka kepercayaan diri akan turun. Lauster (2002) menggambarkan bahwa orang yang mempunyai kepercayaan diri kategori Tinggi memiliki ciri-ciri tidak mementingkan diri sendiri, optimis dan gembira serta tidak membutuhkan dorongan dari orang lain. Ketergantungan terhadap penilaian orang lain merupakan salah satu ciri dari orang yang kurang percaya diri (Lauster, 2002).

Aspek-aspek pembentuk kepercayaan diri adalah ambisi, mandiri, optimis, peduli serta toleransi (Lauster, 2002). Apabila seseorang tidak bisa memenuhi salah satu aspek pembentuk kepercayaan diri seperti interaksi sosial maka seseorang dapat mengalami masalah dengan kecemasan berbicara di depan umum.

Kecemasan berbicara di depan umum dapat dikarenakan adanya ketidakmampuan menyusun pesan sebagai reticence. Retience merupakan sikap tutup mulut atau sikap bungkam yang dialami oleh seseorang. Kesulitan utama reticence bukan pada pengetahuan tetapi ketidakmampuan dalam menyampaikan susunan kata-kata yang telah disiapkan (McCroskey, 2013).

Kecemasan berbicara di depan umum dapat dikategorikan menjadi dua kategori,yaitu state anxiety dan trait anxiety. Kategori state anxiety yaitu hanya mengalami kecemasan pada situasi atau keadaan tertentu. Kecemasan pada kategori trait anxiety yaitu mengalami perasaan kecemasan yang terjadi pada segala bentuk komunikasi (McCroskey, 2013).

Ciri-ciri kecemasan berbicara di depan umum secara fisiologis (misalnya anggota badan gemetar, keringat pada telapak tangan). Ciri kecemasan secara afektif dengan adanya rasa kuatir aspek kognitif seperti kesukaran mengungkapkan kata-kata dan cirri kecemasan perilaku, yaitu menunjukkan perilaku secara umum seperti berjalan- 
jalan di seputar ruangan, tidak dapat duduk dalam waktu lama.

Hasil penelitian yang dilakukan oleh Wahyuni (2014) dengan judul "Hubungan antara Kepercayaan Diri dengan Kecemasan Berbicara di Depan Umum kepada Mahasiswa Psikologi” dengan sampel berjumlah 79 orang mahasiswa, menunjukkan hasil ada hubungan yang signifikan dengan arah negatif antara kepercayaan diri dengan kecemasan berbicara di depan umum dengan $r_{x y}=-0,559$ dan $\mathrm{p}=0,000<$ 0,05 yang artinya ada hubungan negatif yang signifikan antara kepercayaan diri dengan kecemasan berbicara di depan umum. Instrumen yang digunakan dalam penelitian adalah Self Confidence Scale (Skala Kepercayaan Diri) yang mengacu pada teori Lauster (2002) untuk mengukur kepercayaan diri. Sedangkan untuk mengukur kecemasan berbicara di depan umum digunakan Personal Report of Public Speaking Anxiety (PRPSA) dengan teori dari McCroskey (2013).

Sedangkan penelitian yang di lakukan oleh Mutmainah (2016) dengan judul "Hubungan antara Kepercayaan Diri dengan Kecemasan Berbicara di Depan Umum pada Mahasiswa PPL Jurusan BPI" dengan sampel 92 orang mahasiswa yang menunjukan hasil bahwa tidak ada hubungan yang signifikan antara kepercayaan diri dengan kecemasan berbicara di depan umum dengan $r_{x y}=-0,075$ dengan $\mathrm{p}=0,084>$ 0,05 yang artinya tidak ada hubungan yang signifikan antara kepercayaan diri dengan kecemasan berbicara di depan umum.

Berdasarkan topik penelitian yang sama yang dilakukan oleh Wahyuni (2014) dan Mutmainah (2016) tetapi hasilnya bertolak belakang, untuk menjawab hasil mana yang benar di antara keduanya maka perlu di lakukan penelitian ulang oleh peneliti.

Peneliti melakukan pra penelitian kepada mahasiswa Bimbingan Konseling, Pendidikan Sejarah, Matematika, PGSD, Pendidikan Ekonomi dan PPKN tahun angkatan 2016-2017 UKSW Salatiga dengan responden 15 mahasiswa tahun angkatan 2016 dan 15 orang mahasiswa tahun angkatan 2017. Pengambilan responden dengan jumlah 15 per angkatan dikarenakan jumlah tersebut sudah mewakili untuk pengambilan sampel pra penelitian.

Kepercayaan diri yang tinggi sangat berperan dalam memberikan sumbangan yang bermakna dalam proses kehidupan individu, karena apabila individu memiliki kepercayaan diri yang tinggi, maka akan timbul motivasi pada diri 
individu untuk melakukan hal-hal dalam hidupnya.

Sedangkan Menurut Lauster (2002) ciri-ciri individu yang memiliki kepercayaan diri yang rendah adalah individu merasa tindakan yang dilakukan tidak adekuat, individu merasa tidak diterima oleh kelompoknya atau orang lain, individu merasa mudah gugup. Individu merasa cemas dalam mengemukakan gagasannya di depan umum.

McCroskey (2013) menyebutkan bahwa kecemasan berbicara di depan umum termasuk jenis Communication Apprehension (CA) in generalized context. Communication Apprehension adalah kekhawatiran komunikasi yang tingkat kecemasannya dipicu oleh tindakan komunikasi yang nyata atau diantisipasi. Dimana individu mengalami kecemasan berbicara di depan umum saat berada pada situasi tertentu. Kecemasan berbicara di depan umum dapat disebabkan karena rasa takut dan kurangnya percaya diri. Kepercayaan diri yang rendah membuat individu merasa tidak nyaman sehingga menimbulkan kecemasan. Kecemasan hanya pada kondisi tertentu, maksudnya tipe general dari penekanannya adalah bahwa fenomena berbicara di depan umum berpusat pada pembicara. Konteks yang paling banyak di temui adalah berbicara di depan umum misalnya memberikan pidato, presentasi di depan kelas, pada saat pertemuan

Lauster (2002) menyatakan faktor yang mempengaruhi kecemasan berbicara di depan umum salah satunya adalah kepercayaan diri. Semakin tinggi kepercayaan diri maka kecemasan berbicara di depan umum semakin rendah. Begitu juga sebaliknya semakin rendah kepercayaan diri maka kecemasan berbicara di depan umum. Siska (2003) dalam penelitiannya dengan hasil koefisiensi korelasi antara kepercayaan diri dengan kecemasan berbicara di depan umum sebesar $\mathrm{rxy}=0,725$ dengan $\mathrm{p}<$ 0,001 .

Berdasarkan pra penelitian yang telah di lakukan pada mahasiswa FKIP UKSW Salatiga. Sebagian besar mahasiswa progdi Pendidikan Sejarah dengan Kepercayaan diri berada pada kategori rendah $40 \%$ Kecemasan Berbicara di Depan Umum berada pada kategori tinggi 43,3\%, maka peneliti mengangkat judul "Hubungan antara Kepercayaan Diri dengan Kecemasan Berbicara di Depan Umum Mahasiswa progdi Pendidikan Sejarah UKSW Salatiga".

Tujuan dari penelitian ini adalah untuk mengetahui signifikansi hubungan 
dengan arah negatif antara Kepercayaan Diri dengan Kecemasan Berbicara di Depan Umum Mahasiswa progdi Pendidikan Sejarah UKSW Salatiga.

Hasil penelitian ini dapat menjadi masukan Ke Progam Studi Pendidikan Sejarah dalam meningkatkan dan melatih kepercayaan diri selama kuliah kepada mahasiswa sehingga mahasiswa tidak mengalami kecemasan berbicara di depan umum

\section{KAJIAN PUSTAKA}

\section{Kepercayaan Diri}

Lauster menyatakan bahwa kepercayaan diri merupakan suatu sikap atas kemampuan diri sendiri dalam tindakan-tindakannya, dapat merasa bebas untuk melakukan hal-hal yang disukainya dan bertanggungjawab atas perbuatannya, hangat dan sopan dalam berinteraksi dengan orang lain, dapat menerima dan menghargai orang lain, serta dapat mengenal kelebihan dan kekurangannya (Lauster, 2002).

Kepercayaan diri adalah salah satu aspek kepribadian yang penting pada seseorang Tanpa adanya kepercayaan diri akan banyak menimbulkan masalah pada diri seseorang. Kepercayaan diri merupakan atribut yang paling berharga pada diri seseorang dalam kehidupan bermasyarakat. Di karenakan dengan kepercayaan diri, seseorang mampu mengaktualisasikan segala potensi dirinya. Kepercayaan diri diperlukan oleh semua orang.

Menurut Lauster (2002) tentang ciri-ciri orang yang percaya diri adalah sebagai berikut :

a. Percaya pada kemampuan sendiri

b. Bertindak mandiri dalam mengambil keputusan

c. Memiliki rasa positif terhadap diri sendiri

d. Berani mengungkapkan pendapat

Menurut Lauster (2002) aspekaspek yang terkandung dalam kepercayaan diri antara lain :

a. Yakin dengan kemampuan diri

b. Optimis

c. Objektif

d. Bertanggungjawab

e. Rasional dan Realistis

Lauster (2002) memberikan beberapa cara untuk meningkatkan rasa percaya diri yaitu :

1. Sebagai langkah pertama, mencari sebab-sebab mengapa individu merasa rendah diri.

2. Mengatasi kelemahan,

3. Mengembangkan bakat dan kemauannya secara optimal.

4. Merasa bangga dengan keberhasilan yang telah dicapai dalam bidang tertentu dan jangan ragu-ragu untuk bangga atasnya 
5. Bebaskan diri saudara dari pendapat orang lain.

6. Bersikap optimis..

7. Memiliki cita-cita yang realistis dalam hidup.

8. Tidak terlalu membandingkan diri sendiri dengan orang lain.

9. Jangan mengambil sebagai motto ungkapan yang berbunyi, "apapum juga yang dilakukan dengan baik oleh orang lain, sayapun harus dapat melakukannya"

\section{Kecemasan Berbicara Di Depan Umum}

Kecemasan merupakan sebuah perasaan yang dimiliki oleh setiap individu. Munculnya kecemasan melibatkan pikiran dan perasaan negatif sehingga memunculkkan perilaku dan respon yang tidak biasa. McCroskey (2013) membagi

kecemasan berkomunikasi menjadi empat tipe yaitu :

a. Traitlike

Communication

Apprehension

b. Generalized Context Communication Apprehension

c. Audience

Communication

Apprehension

d. Situasional

Communication

Apprehension

McCroskey menyebutkan ada empat ciri yang mempengaruhi kecemasan. Ciri-ciri kecemasan berbicara umum tersebut antara lain :

a. Ciri Suasana Hati

b. Ciri Kognitif

c. Ciri Somatik

d. Ciri Motorik

Faktor yang mempengaruhi kecemasan berbicara di depan umum adalah:

a. Pengalaman negatif di masa lalu

b. Kurang percaya diri

c. Pikiran yang tidak rasional

Menurut McCroskey menyatakan cara untuk mengatasi kecemasan berbicara yaitu dengan :

a. Pikiran irasional

b. Impresi

c. Percaya Diri

\section{METODE PENELITIAN}

Jenis penelitian ini adalah penelitian kuantitatif berjenis korelasional. Penelitian korelasional dalam penelitian ini bertujuan untuk mengetahui signifikansi hubungan antara variabel kepercayaan diri dengan variabel kecemasan berbicara di depan umum. Penelitian ini dilakukan di Progdi Pendidikan Sejarah Universitas Kristen Satya Wacana. Variabel bebas dalam penelitian ini adalah kepercayaan diri. Variabel terikat dalam penelitian ini adalah kecemasan berbicara di depan umum. 
Menurut Sugiyono (2011) populasi adalah wilayah generalisasi yang terdiri dari obyek atau subyek yang menjadi kuantitas dan karakteristik tertentu yang ditetapkan oleh peneliti untuk dipelajari dan kemudian ditarik kesimpulannya. Sedangkan menurut Arikunto (2010) populasi adalah keseluruhan subjek penelitian. Populasi dalam penelitian ini adalah Mahasiswa progdi Pendidikan Sejarah UKSW yang mempunyai kecemasan berbicara di depan umum berdasarkan tahun angkatan .

Teknik pengambilan sampel dalam penelitian ini adalah total sampling. Total sampling adalah teknik pengambilan sampel dimana jumlah sampel sama dengan populasi (Sugiyono, 2011). Alasan mengambil total sampling karena menurut Sugiyono (2011) jumlah populasi yang kurang dari 100 seluruh populasi dijadikan sampel penelitian semuanya. Sampel yang diambil dari penelitian adalah 80 orang.

Metode pengumpulan data yang digunakan yaitu dengan menggunakan Skala. Skala yang digunakan adalah self confidence scale yang disusun oleh Lauster (2002) untuk mengukur kepercayaan diri. Sedangkan untuk mengukur kecemasan berbicara di depan umum menggunakan Personal Report of
Public Speaking Anxiety (PRPSA) yang disusun oleh McCroskey (2013).

Teknik analisis data yang digunakan untuk menguji korelasi antara kepercayaan diri dengan kecemasan berbicara di depan umum dengan data tidak berdistribusi normal menggunakan teknik analisis Kendall's Tau_b (1tailed). Menggunakan Kendall Tau karena dalam penelitian ini jenis datanya ordinal dan datanya juga tidak menunjukkan normalitas dengan sig $0,009 \quad(\mathrm{p}<0,05) . \quad$ Penelitian ini menggunakan bantuan SPSS Version 21.0 for Windows.

\section{HASIL DAN PEMBAHASAN}

Lokasi penelitian yang digunakan adalah di Universitas Kristen Satya Wacana yang terletak di Jl. Diponegoro 52-60, Salatiga. UKSW didirikan pada tanggal 30 November 1956 oleh DR. Oeripan Notohamidjojo. Saat ini UKSW memiliki 59 progam studi salah satunya progam studi Pendidikan Sejarah. Subyek penelitian ini adalah seluruh mahasiswa progdi sejarah yang mempunyai kecemasan berbicara di depan umum sebanyak 80 orang.

Sebelum mengadakan penelitian kepada mahasiwa Pendidikan Sejarah UKSW peneliti telah meminta surat ijin dari Kaprogdi Pendidikan Sejarah UKSW terlebih dahulu. Pengumpulan data 
dilakukan dengan cara melalui google form, yang dapat diakses mulai tanggal 30 Agustus 2018 sampai dengan 30 November 2018. Cara ini dilakukan dengan alasan menghemat waktu dan biaya. Peneliti membagikan link google form kepada responden melalui e-mail dan juga kontak whatsapp. Kemudian peneliti mengecek kembali responden yang belum mengisi dan menemui responden yang belum mengisi kuesioner kepada responden secara pribadi.

Analisis deskriptif yang dilakukan dalam penelitian ini adalah distribusi frekuensi. Untuk mengetahui tinggi rendahnya hasil pengukuran dari variabel kepercayaan diri dan kecemasan berbicara di depan umum maka peneliti mengelompokkan menjadi 5 kategori yaitu Sangat Rendah, Rendah, Sedang, Tinggi, Sangat Tinggi.

Untuk mengetahui hasil korelasi antara Kepercayaan Diri dengan Kecemasan Berbicara di Depan Umum maka pengolahan yang digunakan untuk teknik analisis adalah Uji Korelasi Kendall Tau dengan bantuan SPSS Version 21.0 for Windows.

Dari uji korelasi diketahui koefisien korelasi antara kepercayaan diri dengan kecemasan berbicara di depan umum yaitu rxy $=-0,177$ dengan nilai sig (1tailed) sebesar 0,006 sehingga dapat disimpulkan bahwa ada hubungan yang signifikan dengan arah negatif antara kepercayaan diri dengan kecemasan berbicara di depan umum.

Hasil analisis menunjukkan " Ada hubungan negatif yang signifikan antara Kepercayaan Diri dengan Kecemasan Berbicara di Depan Umum pada Mahasiswa Pendidikan Sejarah UKSW Salatiga." Dengan demikian hipotesis yang diajukan diterima.

Dari uji korelasi diketahui koefisien korelasi antara kepercayaan diri dengan kecemasan berbicara di depan umum yaitu rxy $=-0,177$ dengan nilai sig $(1-$ tailed) sebesar $0,006<0,05$ sehingga dapat disimpulkan bahwa ada hubungan dengan arah negatif yang signifikan antara variabel kepercayaan diri dengan variabel kecemasan berbicara di depan umum. Subyek yang memiliki kecemasan berbicara di depan umum ini juga berada pada kategori tinggi yaitu 53,8\% dan kepercayaan diri berada pada kategori rendah yaitu 46,3\% artinya kepercayaan diri ada hubungannya dengan kecemasan berbicara di depan umum, karena seorang yang mempunyai kepercayaan diri yang rendah menjadikan orang tersebut mengalami kesulitan untuk berkomunikasi dan tidak dapat menerima dirinya karena perbedaan-perbedaan yang di miliki, serta gugup dan cemas dengan 
keadaan yang ada di sekitarnya karena takut orang lain menyalahkannya, percaya diri yang rendah memunculkan kecenderungan mengalami kecemasan saat berkomunikasi seperti saat berbicara di depan umum.

Menurut Sari (2003) dalam penelitiannya juga menjelaskan bahwa individu yang memiliki percaya diri yang rendah menjadi kurang menerima keberadaan dirinya. Kepercayaan diri yang rendah dapat menimbulkan perilaku gugup serta perasaan cemas. Begitu juga yang terjadi pada mahasiswa FKIP Progdi Pendidikan Sejarah UKSW Salatiga yang mempunyai rasa percaya diri yang rendah sehingga memiliki kecemasan yang ada dalam dirinya. Dengan kepercayaan diri yang rendah individu merasa takut mengungkapkan pendapatnya kepada individu lain, takut tidak di terima oleh individu lain maupun kelompok. Sedangkan individu dengan percaya diri yang tinggi mampu menerima keberadaan dirinya sehingga mampu menyesuaikan diri dan berinteraksi secara terbuka dengan individu lain.

Menurut Lauster (2002) individu dengan kepercayaan diri yang tinggi memiliki keyakinan akan kemampuannya, lebih mudah menyesuaikan diri dengan suasana yang menyenangkan sehingga tingkat kecemasannya rendah serta memiliki ketahanan diri yang seimbang. Jika individu dapat meningkatkan dan mengembangkan rasa percaya dirinya maka individu tidak akan merasa cemas apabila berbicara di depan umum.

\section{PENUTUP}

Berdasarkan hasil analisis dan pembahasan disimpulkan ada hubungan negatif yang signifikan antara kepercayaan diri dengan kecemasan berbicara di depan umum yang artinya apabila skor kepercayaan diri turun maka skor kecemasan berbicara di depan umum naik atau apabila skor kepercayaan diri naik maka skor kecemasan berbicara di depan umum turun.

Saran Bagi Pihak Progam Studi Pendidikan Sejarah. Pihak Progdi pendidikan sejarah diharapkan dapat meningkatkan kepercayaan diri mahasiswa sehingga tidak merasa cemas ketika berbicara di depan umum. Kecemasan berbicara di depan umum mahasiswa sebagian besar berada pada kategori Tinggi $(53,8 \%)$ sesuai dengan item pertanyaan pada Personal Report of Public Speaking Anxiety nomor 5 (Saya merasa cemas ketika berbicara di depan umum), item nomor 10 (Tangan saya gemetar ketika saya berbicara di depan 
umum) dan item nomor 13 (Saya selalu takut untuk berbicara di depan umum).

Sedangkan untuk percaya diri berada pada kategori rendah (46,3\%). Pihak progdi pendidikan sejarah diharapkan dapat melatih mahasiswa untuk meningkatkan kepercayaan dirinya sesuai dengan Self Confidence Scale pada item nomor 11 (Saya tidak akan menyerah walaupun teman-teman menertawakan presentasi saya), item nomor 16 (Saya suka kegiatan bersifat kemasyarakatan) dan item nomor 17 (Saya tidak mudah putus asa jika mendapat kritikan dari teman-teman)

Bagi Peneliti Selanjutnya

Bagi peneliti selanjutnya yang tertarik meneliti variabel sama diharapkan dapat memperhatikan dan mengikutsertakan variabel pengaruh lainnya yang dapat mempengaruhi kecemasan berbicara di depan umum misalnya dengan variabel harga diri.

\section{DAFTAR PUSTAKA}

Indrawati, Endang Sri. 2017. Hubungan Antara Kepercayaan Diri dengan Kecemasan Berbicara di Depan Umum pada Mahasiswa UNDIP. Universitas Diponegoro

Lauster, P. 2002. Tes Kepribadian (alih bahasa: D.H. Gulo). Jakarta. PT. Bumi Aksara

McCroskey, J. 2013. The Communication Aprehension Perspective. Sage Publication. New Jersey
Mutmainah, Siti. 2016. Hubungan antara Kepercayaan Diri dengan Kecemasan Berbicara di depan Umum pada mahasiswa BPI. Eprint Walisongo

Sugiyono. 2010 Metode Penelitian Pendidikan: Pendekatan Kuantitatif, Kualitatif, dan $R \& D$. Bandung. Alfabeta

Sugiyono. 2011. Metode Penelitian Pendidikan: Pendekatan Kuantitatif, Kualitatif, dan $R \& D$. Bandung. Alfabeta

Sugiyono. 2015. Metode Penelitian Pendidikan: Pendekatan Kuantitatif, Kualitatif, dan $R \& D$. Bandung: Afabeta

Suharsimi, Arikunto. 2006. Prosedur Penelitian Suatu Pendekatan Praktik. Jakarta: Rineka Cipta

Suharsimi, Arikunto. 2010. Prosedur Penelitian Suatu Pendekatan Praktik. Jakarta: Rineka Cipta

Wahyuni, Sri. 2014. Hubungan antara Kepercayaan Diri dengan Kecemasan Berbicara di Depan Umum pada Mahasiswa BPI. Ejournal Psikologi. Volume 2 